\title{
Daur Chinese
}

National Cancer Institute

\section{Source}

National Cancer Institute. Daur Chinese. NCI Thesaurus. Code C158191.

A Chinese person from the Daur ethnic group. 